\title{
The Classical Languages and Their Actual Contribution - The Case of German and Greek
}

\author{
Dr. Elvis Bramo \\ University of Tirana, Faculty of Foreign Languages, Albania \\ Greek Department \\ E-Mail: elvisbramo@yahoo.com \\ Dr. Salian Cullhaj \\ University of Tirana, Faculty of Foreign Languages, Albania
}

German Department

E-Mail: scullhai@gmx.de

\begin{abstract}
In our research on lexical and linguistic interference from one language to another, the case of the Greek language contact with German has drawn our attention. Greek, as one of the most widespread classic languages in the world, came through the Latin channel to convey her words, mostly science (eg mechanics) and the arts (eg aesthetics) in German-speaking countries.
\end{abstract}

Keywords: Greek, German, word, term, field, linguistics, period, contact, interference

\section{Introduction}

Our initial interest began on how the two languages that share no common borders have a lot of common words, with the same meaning often semantic. The answer is to be found at the interval of the Greco-Roman period, led by Julius Caesar ${ }^{1}$, who constitute the main foundation of this cultural dominance over other nations (around 58 before e.s.) that enabled the language contact of these two languages in this study².

As a result of the economic, social and cultural imposition, was formed the linguistic impact of Greco-Roman culture to the people of other tribes that they conquered. Many inscriptions in Greek in the whole area of Galatia, prove how present the recognition of the Greek in these areas has been, either as an indicator of its presence or as an indicator of the fact that once Greek was considered "lingua franca "that should definitely be spoken by high society classes ${ }^{3}$, where Greek certainly conveyed to the conquered territories through a third language, so the emperor Caesar's Latin. This effect explains how

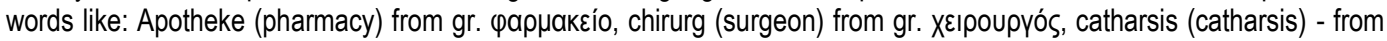

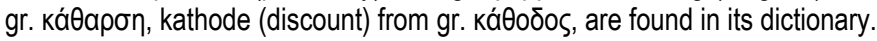

Another period of contact between the barbarian tribes of central Europe and North and South (call barbarian tribes, because at that time the people that were not Roman were consideredj Barbarian) was The Migration Period (Völkerwanderung) circa 450 A.D. who managed to reach as far as the North Africa and reformated the boundaries of the peoples of the time affecting even their former invaders, still deeply in administrative shape, but however gradually moving over to the administrative and terminology terms that they found in their passage through the Roman civilization which

\footnotetext{
1 See Caesar, G. Jul, "De bello gallico", Athens: Grigoris, 2007, Edition:I, paragr. 29.

2 See Georgudakis, E. "Barbarian raids and the decline of the West" A2, Papazisi, Athens 2014, pg. 209.

3 Wierschowski, L., "Fremde in Gallien- Gallier in der Fremde: Die Epigraphisch bezeugte Mobilitat", Sttutgart, Steiner 2001, pg. 448.
} 
prevailed for centuries in these areas. As a result, numerous prisoners and Roman monks that were assimilated into new society forms continued to convey automatically cultural elements of the Greco-Roman civilization also affecting Christianity of the barbarian tribes, but also by trasmitting to them words, as they possessed the power of knowledge in multiple areas and they were maritime traders, slaves, poets, scholars, philosophers, etc. where for the words and the terms used by them there were not equates to the German language and naturally the consequence was that these words would simply adjust their pronunciation. Horace $(65-8 \mathrm{BC})$ said: Graecia capta ferum victorem cepit et artis intulit agresti Latio.

The Gothic language initially as part of the wider family of the German language, from where then differed, reflects in its dimension, although written at IV AD century, a number of Greek vocabulary words transmitted into the German language. It is about a more or less restricted lexicon, because it is mainly the church vocabulary, but containing a lot of paradigm worth mentioning as p.sh .: (Old German) Pfarre - (ahd) Pfarre, paroecia -paroikia -mapoıкía ${ }^{1}$, etc.

The Renaissance of the 15th and the 16th century made the German speaking countries educate their children in gymnasiums in old Greek because the translation of the Holy scriptures by Martin Luther (Martin Luther) brought the need to understand the meaning of these texts in their original language. The Holy scriptures brought through their translations into German, a variety of concepts, names, and phrases that gradually became part of the German language and were now mastered even by simple people who had no previous contact with classical education or more with the Hellenic civilization. Thus, under the influence of operation of high schools and courses that took place in them, the classical Greek language was introduced into the German dictionary until the 19th century.

This gave us the opportunity to find words such as: akropolis, agora, ethos, amfibrachus, autochtoon, autochtonous, palindrome, diaspora, hybris, kosmos, pathos, schisma, cosmos, heureka, epos, delta, pi grek (in geometry), alfa en omega (used metaphorically as an expression), etc. At the field of medicine, German borrowed more word from Greek. Some of them are: diafragma, epidermis, epilepsie, herpes, astma, lepra, dosis, bronchiën, hymen, acne, aorta, clitoris, larynx, meniscus, eczeem, dermatitis, cirrose, oedeem, trauma, colostomy, therapeut, angiogram, leukocyt, and many names names specialization as pediatre, chirurg, psychiatrist, gynecolog, oncolog,etc. Pharmaceuticals also contributed with its paradigms such as glucose, glycerine, kerosine, pepsine etc.

At the sports field Greek led to the promotion of various sports words established in ancient Greece ${ }^{2}$. Words such as marathon, pentathlon, triathlon, decathlon etc.

From the fields of arts we have words like estetic, fotograaf, amfitheatre, bibliotheek, drama, komedie, museum, mysterie, myth, proza, retorica, diploma etc.

In the field of religion we have the word as clerus, kyrie-eleison, apocalyps, apostel, engel, evangelie, orthodoks, patriarch, priester, synagoge etc.

At the field of space science, the ancient Greek scholars had sanctioned this sector terminology with words that dominate as far as today like: astrolog, astronomie, ellips, horizon, komeet, planet etc.

The same happened with the German Martin Kraus (1607) and his works in German Turcograecia and Germanograecia where one can find numerous Greek words.

The development of science and their branches enabled the need terminological vocabulary with lexemes of neologisms from Greek, where it is known, medicine, philosophy, theology, pharmaceuticals, biology, flora and fauna, linguistics, arts and many other fields kept their terms from the Greco-Roman civilization for their branding needs 3 .

These were mainly the motives of entry of the Greek words in German, where beyond the continuous efforts of German linguists on the purification of their language started from the 18th century onward, they continued to be present as it

\footnotetext{
1 Wierschowski, L., "Fremde in Gallien- Gallier in der Fremde: Die Epigraphisch bezeugte Mobilitat", Sttutgart, Steiner 2001, pg. 448. 2 Here we can see how even centuries after the Olympic Games of ancient Greece, the same terms and designations continue to be used so far in different languages of the world.

${ }^{3}$ For more read the Swedish author Carolus Linnaeus, "Psittacula alexandri", Linnaeus 1758
} 
appears in classic expression of texts translated into german, the toponym of the nouns with which even today many Germans baptized as p.sh .: Angela, Dionysius, Agatha, Stephan, Dorothea, Sophia, Andreas, Lydia, Melanie Peter Theodor Helena, Sebastian, Nikolaos, Irene ${ }^{1}$, etc. Hektor. Toponyms as Kristianopel, Palaiocome, Neanderthal began settling in German cities because of the admiration that the German King Ludwig the first had for Greece and the Greek civilization whom beyond the fact that some buildings in Bavaria where built in the style of ancient Greece in 1825 his son, prince Otto, was sent as the first king of free Greece.

Browsing the German dictionary: "Duden, Deutsches Universal Wörterbuch." we note that technical ${ }^{2}$ terms are commonly found either adapted to the rules of German or completely left just as in borrowing language:: topos - from gr. Tómos, the word idiot gr. Old ıঠı

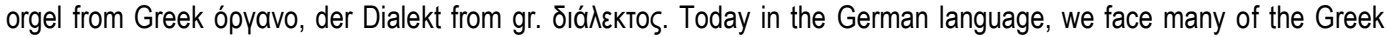
prefixes used in the technique words in German. Prefixes as aero, neo, hyper, pneuma, tele, syn, kosmo, bio, astro, auto, anti, agro, elektro, homo, demo etc., which have found thier way into German through her contact with Latin as we explained above.

Not a few are composites with suffixes from Greek as:

-gram at the word hologramm from gr. o\óypa $\mu \mathrm{a}^{3}$

-logie from gr. 入oyía.

-skop from gr. бKómiov

-thik from gr.Өńkn

-pathie from gr. пá $\theta \varepsilon ı$.

-id from gr. عí̄ns.

Leaving somewhat aside borrowings starting from the 15th and the 16th century, we see that even today German tourists contacts with Greeks has made possible the entry of certain words in the modern period mainly culinary words like ph: ouzo, souvlaki, retsina, tzatziki, moussaka, gyros etc.

From the Linguistics and rhetoric we come across words as:

Epithet, idiotic, litotes, prolegomena, lexicon, por kemi edhe fjalë si: etymologicon, hexameter, zeugma,oxymoron, polysyndeton.

Interesting too are some of the expressions found in Emmanouil Geogudakis linguist studies that he mentions in one of his articles: Das A und O, Unter der Ägide, Trojanisches Pferd, Danaidenfass, Gelegenheit beim Schopf packen, Kassandrarufen, Pyrrhussieg, Sisyphusarbeit, Zankapfel. All these expressions exist today and will be so in the future in use in the German language, as all these centuries failed to change anything inside them.

\section{Conclusions}

The classical languages served as an inexhaustible treasure for today's terminology of many Western languages in this setting they gave their indisputable contribution in the German language. Numerous examples from different fields of life more than knowledge testify openly this phenomenon.

\footnotetext{
${ }^{1}$ For more refer to, Günther Steffen Henrich, "Von Kristianopel bis Kiritimati. Heutige Ortsnamen griechiescher Etymologie außerhalb des griechischen Kernraumes", Ekkehard Stärk, Philologus nr. 141.

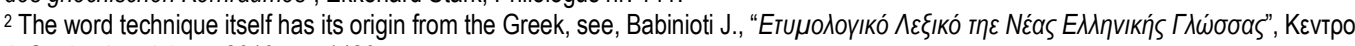

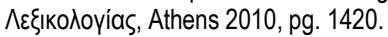

${ }^{3}$ Kaufman, Pons. "Kompaktwörterbuch", deutsch- neugriechisch, Stuttgart 1997, pg.384
} 
The contribution of classical languages in the field of lexicology not even today represents a linguistics problem to clear the language from the terms of classical sources, because these words have been completely assimilated, so that the users of Western languages where classical languages mainly find their space do not feel them as foreign. This distinction can manage only someone who is fluent in old and new Greek, and also in Latin. Most users perceive these words in the context of a functional individual and collective bilingualism and they can not distinguish them from the vocabulary of their native language.

\section{References}

[1] -Carolus Linnaeus, "Psittacula alexandr", Linnaeus 1758

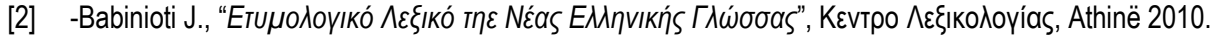

[3] -Georgudakis, E. "The Barbarian raids and the decline of the West" A2, Papazisi, Athens 2014.

[4] -Günther Steffen Henrich, "Von Kristianopel bis Kiritimati. Heutige Ortsnamen griechiescher Etymologie außerhalb des griechischen Kernraumes", Ekkehard Stärk, Philologus nr. 141.

[5] -Kaufman, Pons. "Kompaktwörterbuch", deutsch- neugriechisch, Stuttgart 1997.

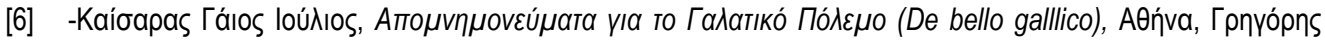
2007.

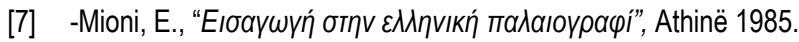

[8] -Royen, Gerlach, Latin en Grieks dat wij allen spreken, Amsterdam, 1954.

[9] -Sophocles, E.,A., History of the Greek Alphabet and Pronunciation, Cambrige: J Barlett, 1854.

[10] -Wierschowski, L., "Fremde in Gallien- Gallier in der Fremde: Die Epigraphisch bezeugte Mobilitat", Sttutgart, Steiner 2001.

[11] -Weise, Fr., O., Die griechischen Wörter im Latein, Leipzig, 1964. 